\title{
醸造酵母の生菌数の酸素センサによる 迅速推定
}

酵造食品中に生存する酵母を迅速に測定する方法の 1 つとして，カタラーゼ活性を測定して，直ちに酵母数と してアウトプットする方法の研究の現状と実用性について解説していただいた。

大橋実

\section{1. は じめに}

酸素さンサは発醳工程の通父管理や酒類の品質管理な どによく利用されているものであるが，微生物のカタラ 一ゼ活性の测定にも便利な七ンサである。醇造酵母の増 雃過程のカタラービ活性の消長を酸素さンサ法で測定 し, 生菌数の讯速推定を試みた研究の一端を紹介した

\section{2. 測定法の原理}

カタラービ活性の測定には通常過酸化水素 $\left(\mathrm{H}_{2} \mathrm{O}_{2}\right)$ の

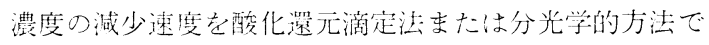
测定寸る力法が用いられる。滴定法では短時間の测定が 不可能でする。また， $240 \mathrm{~nm}$ の吸光度変化を自動測定 ナる分光法は酸素ガス発生によるノイズが避けられない などの難点がある。しかし，筆者らが検討してきた酸素 カンサ法1)では，溶毒酸素（DO）を除去した検液に $\mathrm{H}_{2} \mathrm{O}_{2}$ を添加し, 力タラービの作用で生成するDOの変 化を自動的に澌定記録して，その变化速度から力タラー ざ活性を正確かつ迅速に测定することができる。

(1) 式に示すよらに, $\mathrm{H}_{2} \mathrm{O}_{2} 2$ モルの分解により1 1 ルの $\mathrm{O}_{2}$ が生成する。この化学量論関係に基つき, DO の生成速度から $\mathrm{H}_{2} \mathrm{O}_{2}$ の分解速度が求められる。

$$
2 \mathrm{H}_{2} \mathrm{O}_{2} \stackrel{\text { カタラーゼ }}{\longrightarrow} 2 \mathrm{H}_{2} \mathrm{O}+\mathrm{O}_{2}
$$

この反応を行う温度 $30^{\circ} \mathrm{C}$ での JIS-K-102 記載の DO 表上の水の飽和溶存酸素量 $(7.53 \mathrm{mg} / l)$ は, モル濃 度に換算すれば $0.235(\mu \mathrm{mol} / \mathrm{ml})$ となる。この溶存酸素 濃度は（1）式の関係に基ついて考えると, その 2 倍の モル濃度 $(0.47 \mu \mathrm{mol} / \mathrm{m} l)$ の過酸化水素に相当する関倸 にある。

こうした関係を利用すれば，品気飽和水を $\mathrm{H}_{2} \mathrm{O}_{2}$ の標 準液に代用して DO ヒンサの出力を $\mathrm{H}_{2} \mathrm{O}_{2}$ 濃度に容易
に換算できる。

\section{3. 実 験 方 法}

\section{1 カタラーゼ活性測定装置}

上記した原理によるカタラーゼ活性測定における妨害 因子は検液中の既存 DO である。すなわち，そのまま $\mathrm{H}_{2} \mathrm{O}_{2}$ 分解をすれば DO が過飽和レベルとなり，その一 部がガス化しへッドスペースに逃げる䛊差を生じるから である。この䛊差を避けるために，筆者は第 1 図に示し た $\mathrm{N}_{2}$ ガスによる DO 除去機構を備えた DO センサ付 の $\mathrm{H}_{2} \mathrm{O}_{2}$ 分析計を開発し，これをカタラーゼ活性測定に 応用し好結果を得た。

本装置は厚生省の要請により, 食品添加物の $\mathrm{H}_{2} \mathrm{O}_{2}$ 分 析装置として開発されていたものである21。

その後, マイクロプロセッサー内蔵によって操作性を 高めた, 過酸化水素計, SUPER ORITECTOR ${ }^{\circledR}$ MODEL 5 (オリエンタル電気(株)) が製品化されたので, こ れにカタラーゼ活性演算プログラムを付加して用いた。

なお，この過酸化水素計に $1 \mathrm{mV}$ フルスケール感度の ペン記録計（大倉電気 (株) 製, デスタトップレコーダ ー・モデル DR 1112 AOO 型) および反応セルの温度制 御用恒温水槽 (タイテック (株) サーモミンダー $\mathrm{Jr}-80$ ) を組み合せて本研究に用いた。本装置は MODE スイッ チの切り換えにより過酸化水素, カタラーゼ活性の両方 を測定できる。

\section{2 酵母の培養装置および培養方法}

Monod 式振とう培養装置（大洋化学工業（株）製, UNIT SHAKER MONOSIN II ${ }^{\mathrm{A}}$ ) に直径 $18 \mathrm{~mm}$ のL 型試験管をセットして下記の醸造酵母 3 株を好気的に培 養し，增殖とカタラーゼ活性との関係を検討した。 く振とう培養条件〉

培養温度 : $30^{\circ} \mathrm{C}$

A. Rapid Method for Estimation of Viable Cell Count of Brewing Yeast Using an Oxygen Sensor System Minoru OHASHI (Moritex Co., Ltd.) 


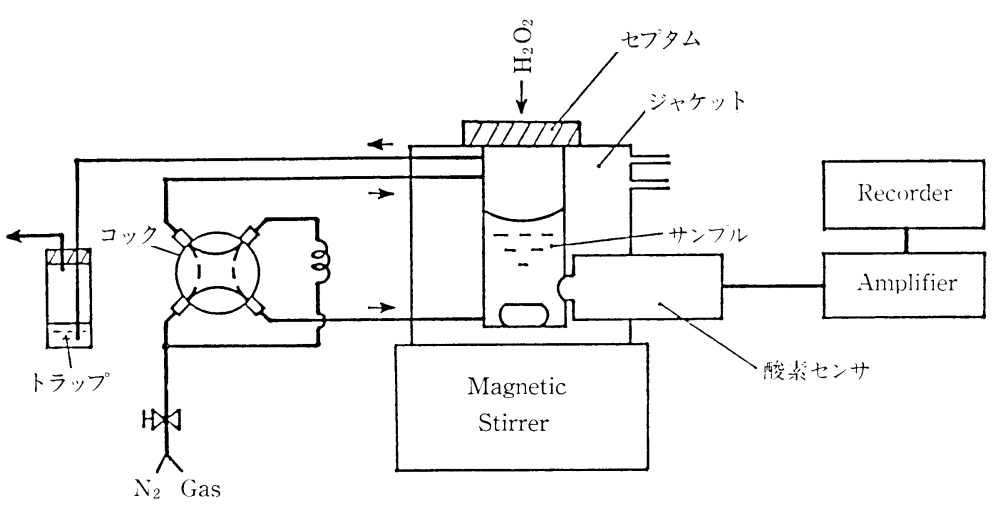

第1図 酸素センサによるカタラーゼ活性测定装置略図

振とう回数 : 80 stroke $/ \mathrm{min}$

培地量 : $5 \mathrm{ml}$

酸素供給速度 $\left(K_{d}\right): 7.6 \mathrm{mmol} \mathrm{O}_{2} / l / \mathrm{min} / \mathrm{atm}$. (亜 硫酸塩法 $)^{3)}$

<培地組成>

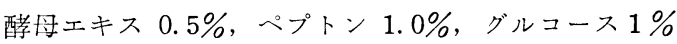
十水

〈培養拈よび経時的測定〉

$\frac{\text { スラント }}{\text { 一白金耳 } \downarrow \text { 接種 }}$

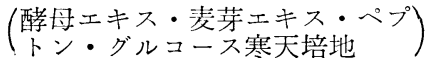

前培養

$(20 \mathrm{hr})$ （試験管 1 本）

$50 \mu l \downarrow$ 接種

本培養 (定常期まで, 試験管複数本に分け $)$

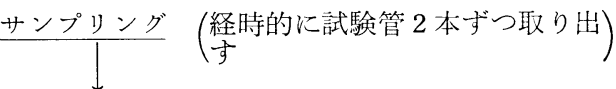

測定 (カタラーゼ活性, 生菌数*, 濁度**)

*メチレンブルー染色後,トーマ血球計算板で測定。

** L 型試験管を挿入し, BAUSCH \& IOMB の分光光度計 で $\mathrm{OD}_{660 \mathrm{~nm}}$ を測定して图濃度を測定。

$<$ 供試菌株 $>$

理化学研究所微生物系統保存施設, 東京大学応用微生 物研究所 (現・分子細胞生物学研究所) 等より分譲を受 汁た下記保存菌株を用いた。

Saccharomyces cerevisiae JCM 2220

(ワイン酵母)

Saccharomyces cerevisiae JCM 7255

(上面発酵ビール酵母)

Saccharomyces cerevisiae IAM 4512

（清酒酵母協会 6 号菌）

これらはスラントに植えて冷蔵庫に保存し, 1 力月毎 に継代培養して用いた。

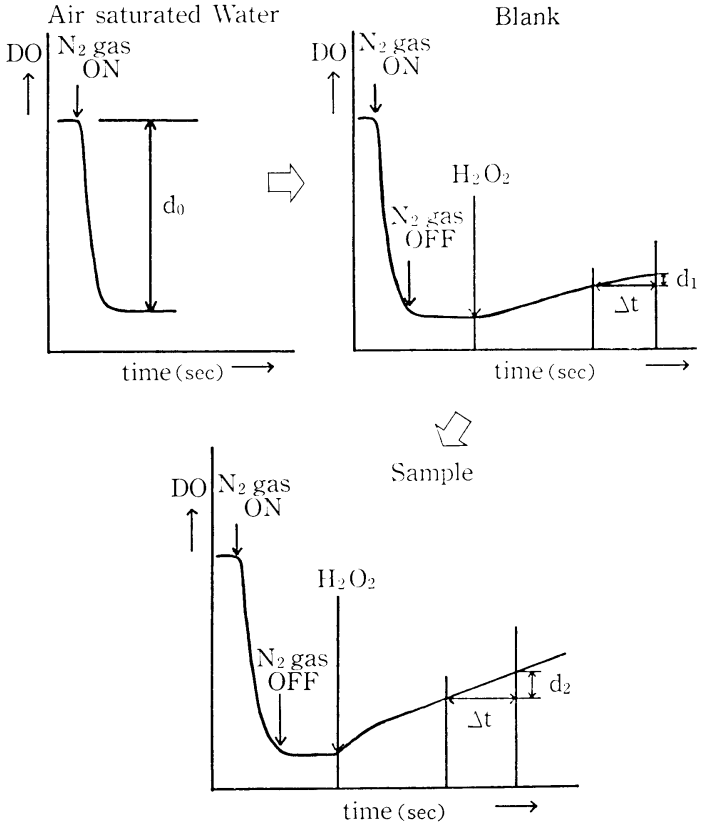

第 2 図 カタラーゼ活性の測定手順説明図

\subsection{DO センサによるカタラーゼ活性測定法}

カタラーゼ活性を測定するための反応条件として最初 $30^{\circ} \mathrm{C}, \mathrm{pH} 7.0$, 基質 $\mathrm{H}_{2} \mathrm{O}_{2}$ の初濃度 $10 \mathrm{mM}$ の従来の標 準的条件 ${ }^{4}$ を採用した。しかし, 中途で pH 7.0 では基質 の自然分解がおこり，ブランク值が増大し不安定化する ことに気付いた。最終的に pH 6.0 の微酸性りン酸綵衝 液での反応条件がブランクの值が低く安定化することを 確認して, pH 6.0 に変更した。

な拉, $\mathrm{H}_{2} \mathrm{O}_{2}$ 試薬には安定性の高い三德化学工業 (株) 製特級品（濃度 $30 \%$ ）を用いた。

操作手順としては, まず計器の反応七ルに $30^{\circ} \mathrm{C}$ で空

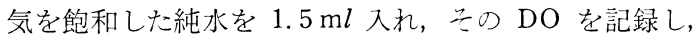


$\mathrm{N}_{2}$ ガスを続いて澊入して DO を除去し飽和 DO に対 するDO 出力のスパン do を確認する（第 2 図左上部 の曲線 “Air Saturated Water” 参照)。

次に反応七儿内液を $0.05 \mathrm{M}, \mathrm{pH} 6.0$ のリン酸緩衝液 $1.47 \mathrm{~m} l$ に替元た後, 再び DO を除き, $\mathrm{N}_{2}$ ガスの尊入を 止的た後にDOを吉らかじめ除去した $500 \mathrm{mM} の \mathrm{H}_{2} \mathrm{O}_{2}$ 溶液 $30 \mu l$ を密閉した反応セルの注入口からシリコンゴ ムのセプタムを介して注入して, 反応セル内の $\mathrm{H}_{2} \mathrm{O}_{2}$ 濃 度を $10 \mathrm{mM}$ に調整し, 約 1 分間 $\mathrm{H}_{2} \mathrm{O}_{2}$ の自然分解によ るDO の上昇を記録しブランク曲線を得る（第 2 図右 上部 “Blank” 参照)。

続いて, $0.05 \mathrm{M}, \mathrm{pH} 6.0$ のリン酸緩衝液に愳濁した 酵拇試料 $1.47 \mathrm{ml}$ を入れ，脱気後基質 $\mathrm{H}_{2} \mathrm{O}_{2} 30 \mu \mathrm{l}$ を注 入して第 2 圆下部沪示す曲線 “Sample”を得る。そして $\mathrm{H}_{2} \mathrm{O}_{2}$ 注入後約 10 秒後に示される直線部分の勾配から $\mathrm{H}_{2} \mathrm{O}_{2}$ の分解速度を求め, カタラーゼ活性 $\left(R_{i}\right)$ とする。 な寺, この上らにして求めた分解速度は $\mathrm{H}_{2} \mathrm{O}_{2}$ の分解の 一次反応速度定数と高い相関を有するものである5)。 $R_{\imath}$ の計算式は（2）式により行った。

〔なお， $R_{\imath}$ の值を 60 倍するとカタラーゼ国際単位 ( $\mu \mathrm{mol} \mathrm{H}_{2} \mathrm{O}_{2} / \mathrm{min} / \mathrm{ml}$ ) の活性值を得る]。

$$
R_{\imath}=2 \times C_{0} \times\left\{\left(d_{2}-d_{1}\right) / d_{0}\right\} \times(1 / \Delta t) \times(V / v)
$$

たな゙し，

$R_{\imath}$ : カタラーゼ活性 $\left(\mu \mathrm{mol} \mathrm{H}_{2} \mathrm{O}_{2} / \mathrm{sec} / \mathrm{m} l\right)$

$C_{0}$ : 空気飽和水の溶存酸素濃度 $(0.235 \mu \mathrm{mol} / \mathrm{ml}$, $\left.30^{\circ} \mathrm{C}\right)$

$d_{1}:$ ブランク試験での $\Delta t$ に预汁るセンサの振虹幅 $(\mathrm{cm})$

$d_{2}$ : 試料による試験での $\Delta t$ におけるセンサーの振れ 㜚 $(\mathrm{cm})$

$d_{0}$ : 空気飽和水に対するセンサの振れ幅 $(\mathrm{cm})$

$\Delta t:$ 反応時間 $(\mathrm{sec})$

$V$ : 反応液量 $(\mathrm{m} l)$ 本実験では $1.5 \mathrm{~m} l$

$v$ : 試料液量 $(\mathrm{m} l)$ 本実験では $1.47 \mathrm{~m} l$

なお, コンピュータ内蔵の装置は $\mathrm{N}_{2}$ ガスの導入およ び停止, $\mathrm{H}_{2} \mathrm{O}_{2}$ 注入時期の指示, カタラーゼ活性值の計 算, 表示等が自動化されている。また，測定時間 $\Delta t$ は 10〜30 秒の間に設定できるようにした。

なっ, single cell 㟧たりの平均的なカタラーゼ活性

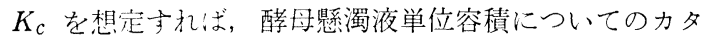
ラ一七活性 $R_{\imath}$ と $K_{c}$ との間には (3) 式の関保が成り 立つので, この式を用いて酵母の増殖過程における $R_{\imath}$, $N$ の測定値を（3）式に入れ $K_{c}$ の值を計算した。

$$
R_{\imath}=K_{c} \cdot N
$$

たな゙し，
$K_{c}$ : カタラーゼ活性係数 ( $\mu$ mol $\mathrm{H}_{2} \mathrm{O}_{2}$ decomposed/ sec/single cell)

$R_{i}$ : カタラーゼ活性 ( $\mu \mathrm{mol} \mathrm{H}_{2} \mathrm{O}_{2}$ decomposed/sec/ $\mathrm{m} l$ )

$N:$ 生菌数 (cells $/ \mathrm{m} l)$

\section{4. 測定結果と検討課題}

\section{1 好気培養系における測定}

前記した培養方法により，第 $3 ， 4$ 図に示すように各 酵母菌株について定常期の後期に至るまで培養を行い, 経時的にサンプリングし, 前記方法により濁度 (O.D), 生菌数 $(N)$, カタラーゼ活性 $\left(R_{\imath}\right)$ を測定した。

また, 対数增殖期における各菌株の比增殖速度 $\left(\mu^{-\mathrm{hr}}\right)$ を增殖曲線から求めた結果を第 1 表に示した。最大増殖 速度係数 $\left(\mu_{\max }\right)$ 相当值が示されたものと判断される が，ビール酵母の JCM 7255 株はワイン酵母の JCM 2220 株に比べ，かなり小さい值を示したことが注目さ れた。

しかし，いずれの菌株においても，培盖液のカタラー セ活性 $R_{\imath}$ は生菌数 $N$ の増加によく似た傾向の变化を示 した。この結果から（3）式の変形式である（4）式が 近似的に成立することになると考光た。そうなれば $K_{c}$

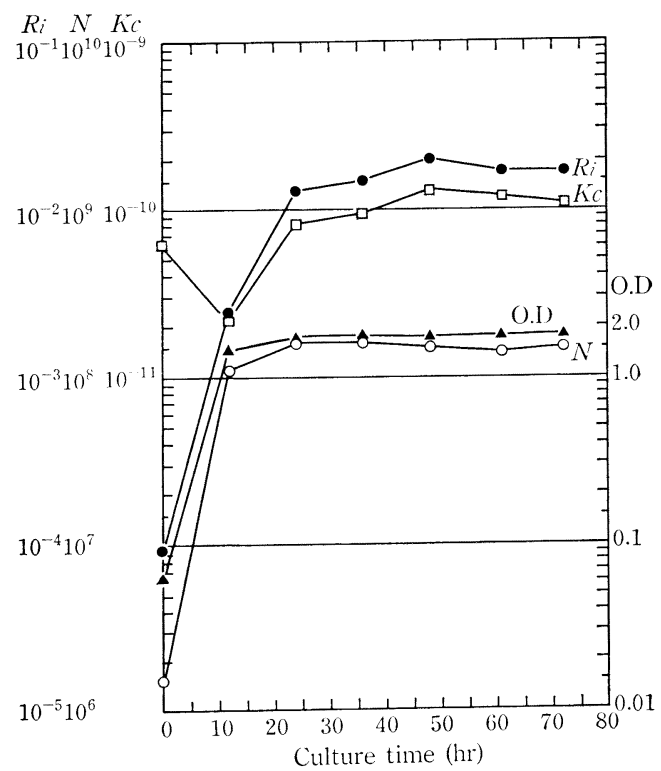

第3図 S.cerevisiae JCM 2220 (ワイン酒酵母) の好気培盖に打ける增殖とカタラーゼ活性
$N \bigcirc \cdots \cdots$. 生菌数 $($ cells $/ \mathrm{m} l)$
O.D $\mathbf{\Delta} \cdots \cdots . \Delta$ ブロスの濁度 $\left(\mathrm{OD}_{660 \mathrm{~nm}} \times 10 \mathrm{~mm}\right)$
$R_{i}$
ブロスのカタラーゼ活性

$K_{\text {。 }}$ $\left(\mu \mathrm{molH} \mathrm{O}_{2} / \mathrm{sec} / \mathrm{m} l\right)$ 


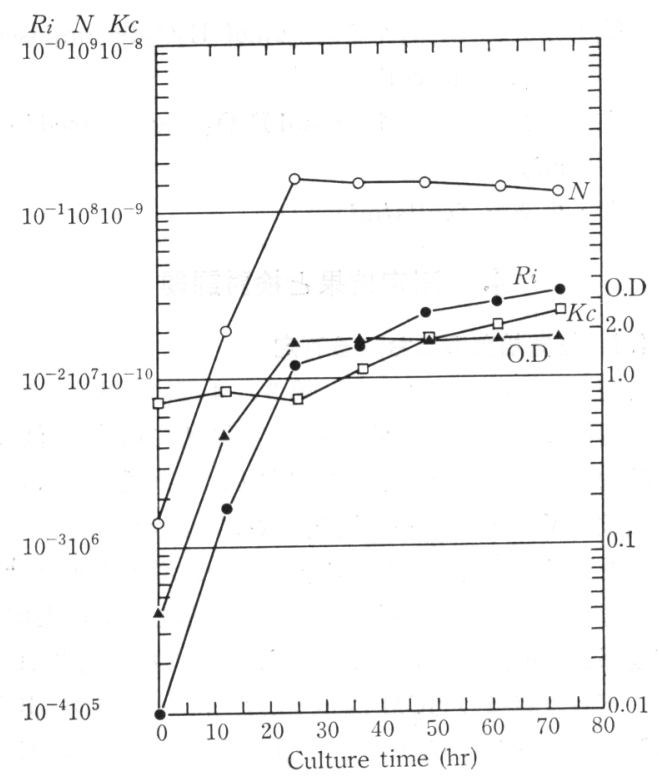

第4 図 S. cerevisiae JCM 7255 (ビール酵母) の好気培養に打ける増殖とカタラーゼ活性
$N \bigcirc \cdots \cdots \bigcirc$ 細胞数 (cells $/ \mathrm{ml}$ )
O.D $\mathbf{\Delta} \cdots \cdot \mathbf{\Delta}$ ブロスの濁度 $\left(\mathrm{OD}_{660 \mathrm{~nm}} \times 10 \mathrm{~mm}\right)$
$R_{i}$ …… ブロスのカタラーゼ活性

$K_{0} \quad \square \cdots \cdots \cdot \square$ カタラーゼ活性係数

$\left(\mu \mathrm{molH}_{2} \mathrm{O}_{2} / \mathrm{sec} / \mathrm{m} l\right)$

( $\mu \mathrm{molH}_{2} \mathrm{O}_{2}$ decomposed/sec/single cell)

第 1 表 培養酵母の比增殖速度 $(\mu)$

\begin{tabular}{c|c}
\hline \hline 酵 母 & $\mu\left(\mathrm{hr}^{-1}\right)$ \\
\hline S.cerevisiae JCM 2220 & 0.358 \\
S.cerevisiae JCM 7255 & 0.222 \\
\hline
\end{tabular}

值が確認できた菌株では $R_{\imath}$ の測定值から検液中の $N$ の 概数を（4）式から推算することが可能となる。図示の ように, 定常期の各酵母の $K_{c}$ の值は $1 \sim 2 \times 10^{-10}$ ( $\mu$ mol decomposed $\mathrm{H}_{2} \mathrm{O}_{2} /$ sec/single cell) の活活一定值 を示した。

$$
N \fallingdotseq R_{\imath} / K_{c}
$$

な拈; 対数增殖期にお沙る $K_{c}$ の変化を見る之, 対数 增殖期にやや低下して定常期汇回復する傾向が認められ た。これとよく類似している現象は KOYAMA ら ${ }^{61}$ とより S. cerevisiae (パン酵母菌株) について以前に報告された ものであるが，これ以外の酵母種にも類似の現象の生じ ることを示した結果である。

上記の Koyama らは対数增殖期に求ける $K_{c}$ の低下 現象を基質グルコースがカタラーゼ形成に抑制効果を及 ぽすためとしているが，本実駼においてもグルコースが 泳涪消費しつくされた定常期に $K_{c}$ が回復しているので
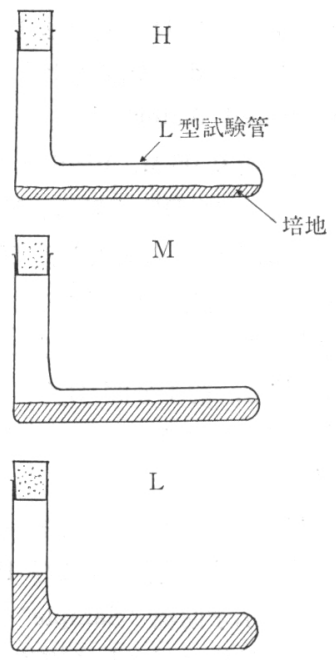

第 5 図 酸素供給速度 $\left(K_{d}\right)$ の調整法 $\left(\mathrm{H}, \mathrm{M}, \mathrm{L} の K_{d}\right.$ 值は第 2 表に示す)

同様の効果によると考光られる。

また，EPHRUSSI ら》は比較的高濃度のグルコースを含 む培地で好気的に培養した酵母細胞の呼吸能が, 対数增 殖期に減少し定常期に回復することを示して㐨り，この 呼吸能の変化は細胞の $K_{c}$ の動向之非常に似ているよう である。

\section{2 酸素供給が制限された嫌気的培養における測定}

上記の結果は酵母の培養環境因子の酸素供給が十分な いわゆる好気条件下に得られたものである。

各種醸造工程に打いては, むしろ酸素供給が制限され た条件が多いと考光られるので，カタラーゼ活性がどの ような影響を酸素の制限により受けるかを以下のモデル 実験により検討した。

本実験にも，S.cerevisiae に属する JCM 2220 (ワイ ン酵母）扣よび JCM 7255 (ビール酵母）の2 株を用い た。

培養中の酸素の供給度は第 5 図に示したよらに, 培地 の量を増すことにより空気との接触面積を減少させる方 法で制限した。培養液量が $26 \mathrm{~m} l$ のものは酸素供給速度 $\left(K_{d}\right)$ の測定を行っていないが， L型試験管の首まで培 養液で満たされ振とう中も培養液が汪とんど動かないの て嫌気培養に非常に近い状態のモデルとみなした。

なお，培養は前培養，本培養ともそれぞれレベルの異 なる酸素制限条件下で振とう培養を行った。ただし，本 培養の開始時に菌数に大差がないよう接種量を適宜調整 した。培養液量と $K_{d}$ との関連は第 2 表のようである。 な抒, 培地組成, 培盖温度打よび振とう速度は前記の 通りである。 
第 2 表 振とう培盖に拈壮る培養液量と酸素供給速 度 $\left(K_{a}\right)$ との関係

\begin{tabular}{c|c|c}
\hline \hline 培養液量 $(\mathrm{m} l)$ & $\begin{array}{c}\text { 酸素供給速度, } K_{d}{ }^{*} \\
\left(\mathrm{mmol} \mathrm{O}_{2} / \mathrm{m} l / \mathrm{atm}\right)\end{array}$ & 酸素供給レベル \\
\hline 5 & 7.61 & 高 $(\mathrm{H})$ \\
10 & 1.61 & 中 (M) \\
25 & $\risingdotseq 0$ & 低 (L) \\
\hline
\end{tabular}

* 覀硫酸塩法 ${ }^{3)}$ で剆定

$<$ 測定 $>$

$\mathrm{H} ， \mathrm{M} ， \mathrm{~L}$ の酸素供給条件の各サンプルについて濁度 $(\mathrm{O} . \mathrm{D})$, 生菌数 $(N)$, カタラーゼ活性 $\left(R_{i}\right)$ を測定し, カタラーゼ活性係数 $\left(K_{c}\right)$ および比增殖速度 $(\mu)$ を計 算した。またDO センサ法により呼吸能を調べた。

<結果と考察 $>$

酵母の増殖とカタラービ活性との関係に及洔酸素供 給度の影響を理解するために, 生菌数 $(N)$ とカタラー ゼ活性係数 $\left(K_{c}\right)$ に注目して検討した結果を第 6,7 図 に示した。S.cerevisiae JCM 2220, JCM 7255 のいずれ も $K_{d}$ の減少に応じた増殖抑制が培養過程における生菌 数 $(N)$ の消長に示された。すなわち， HとLを比較す ると， $K_{d}$ の最も低い $\mathrm{L}$ の生菌数は定常期において $K_{d}$

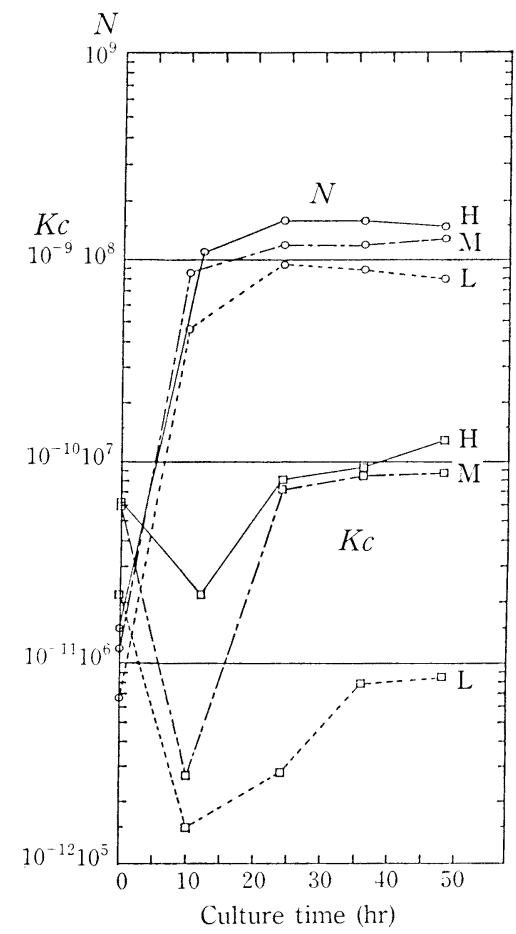

第 6 図 異なる酸素供給速度における

S. cerevisiae JCM 2220 の増殖

とカタラーゼ活性係数の消長

$K_{c} \quad \square \cdots \cdots \cdot \square$ カタラーゼ活性係数 $\left(\mu \mathrm{molH}_{2} \mathrm{O}_{2}\right.$ decomposed $/ \mathrm{sec} / \mathrm{single}$ cell)

$N \bigcirc \cdots \cdots \bigcirc$ 細胞数 $($ cells $/ \mathrm{ml})$
Kc $\quad N$

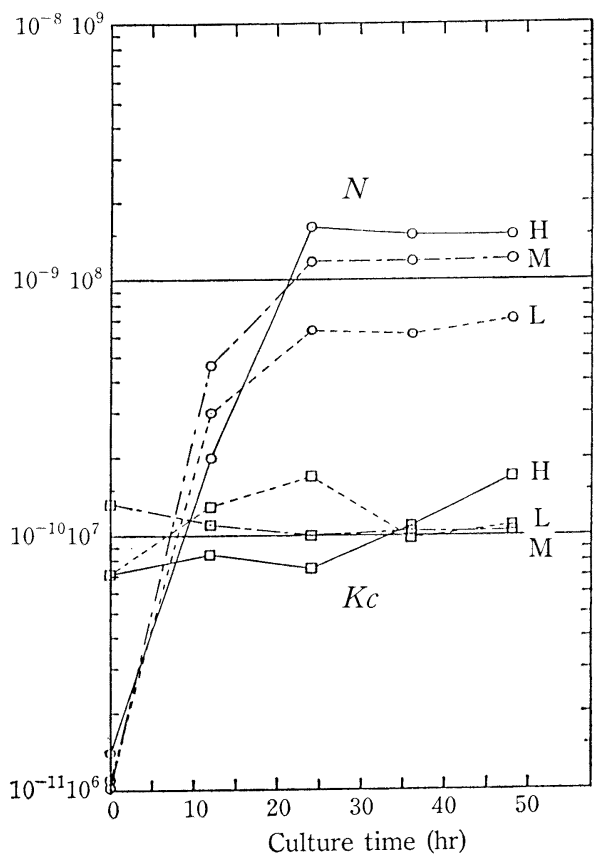

第 7 図 異なる酸素供給速度に括ける S. cerevisiae JCM 7255 の増殖 とカタラーゼ活性係数の消長

$K_{c} \quad \square \cdots \cdots \cdot \square$ カタラーゼ活性係数 $\left(\mu \mathrm{mol} \mathrm{H}_{2} \mathrm{O}_{2}\right.$

$N \bigcirc \cdots \cdots \bigcirc \quad \begin{aligned} & \text { decomposed } / \mathrm{sec} / \mathrm{s} \\ & \text { 細胞数 (cells } / \mathrm{m} l \text { ) }\end{aligned}$

最高のHのほぼ $1 / 2$ に過ぎない結果であり，酸素供給 が増殖に顕著な影響を与えることが示された。

次にカタラーゼ活性についてみると，第6 図に示した よらに JCM 2220 のワイン酵母に沶いては， H（K⿸ $7.61)$ と $\left(K_{d} \doteqdot 0\right)$ を比較すると, 後者の $K_{c}$ は好気 的培養菌体の約 $1 / 10$ に相当する小さい值となることが 示された。ところが，JCM 7255 のビール酵母において は第 7 図に示したように, 酸素供給量の影響を汪とんど 受けていないとみられる結果が示され，菌株によっても カタラーゼ形成についての酸素の影響の受けかたに違い のあることを示唆する結果が得られた。

なお，DO センサ法により呼吸活性を酵母懸濁液の DO 呼吸速度から定性的に検查したところ，Hの条件で 増殖した酵母は強い呼吸能を示し，Mの場合はより低い 呼吸能を示したのに対し，Lの場合は呼吸能はきわめて 微弱であった。好気的な培養過程において, 酸素の刺戟 により呼吸をつかさどるミトュンドリアの形成されるこ とが詳しく研究されているが，ペルオキシソームの構成 要素であるカタラーゼの生成とミトコンドリア生成との 相互関係はどのようなものであろらかとの與味が持たれ るところである。 


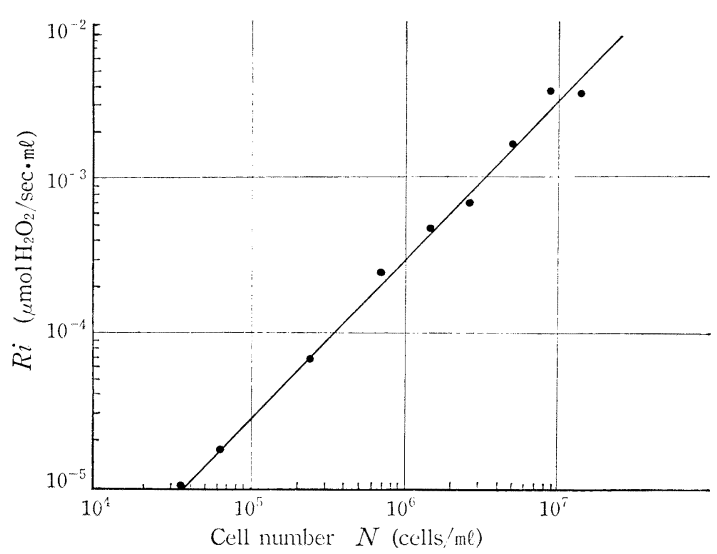

第 8 図 清酒酵母 (S. cerevisiae IAM 4512) の細 胞数 $(N)$ とカタラーゼ活性 $\left(R_{i}\right)$ との関係

今後同装置を用いてさらに検討したい。

\section{5. 酵母生菌数推定の可能性の検討}

DO センサによる醉母のカタラーゼ活性の迅速測定に ついての検討の結果をのべた。従来, この測定法は後記 するように食品の微生物污染度の迅速検查法として食品 衛生学の立場から注目される研究が発表されているが, 筆者は，酵母を主たる材料として測定法の基礎的吟味を

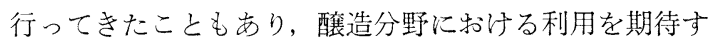
るものである。第 8 図は, S.cerevisiae IAM 4512 (協会

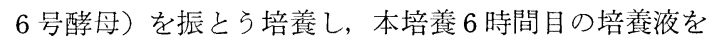
リン酸緩衝液で菌濃度 $10^{4} \sim 10^{7} \mathrm{cells} / \mathrm{m} l$ の範囲に希釈 し, 各液のカタラーゼ活性を測定した結果である。カタ ラーゼ活性 $R_{\imath}$ と生菌数 $N$ との間に広範囲の直線関係が 認められた。このような検量線を用いて清酒もろみや酒 母の生菌数の迅速推定を行い, 清酒醸造の管理に利用で きるかについては, 実際の工程において検討を要すると 考兄られる。

第 3 表に示す結果は, 中央味噌研究所・海老根所長の 御厚意により入手した産地の異なる味噌試料について, 平板培養法で測定した酵母のコロニ一数とカタラーセ活 性との関係を検討した結果である。平板培責については コロニ一数判定時期が早寸ぎたためか確認不能なものも あったが、コロニーが確認されたものについてはカタラ 一ゼ活性も大きかった。少数例の予借的実験の範囲を脱 しないもので, 本誌上に紹介するに尚早の感を否め好 のであるが，参考までに追加させていただいた。

本稿では, 醉造酵母の純粋培養系における酵母増殖と カタラーゼ活性との関係を紹介したが, 実際の醸造過程 に扮いては酵母以外のカタラーゼ陽性菌の存在を無視す
第 3 表 味噌の菌数とカタラーゼ活性の相関

\begin{tabular}{|c|c|c|}
\hline \multicolumn{2}{|c|}{ 菌数 (cell/g) } & $\mathrm{H}_{2} \mathrm{O}_{2}$ 分解初速度 $\left(\mu \mathrm{mol} \mathrm{H}_{2} \mathrm{O}_{2} / \mathrm{g} \cdot \mathrm{sec}\right)$ \\
\hline A & - & $1.86 \times 10^{-1}$ \\
\hline B & - & $2.59 \times 10^{-1}$ \\
\hline $\mathrm{C}$ & $1.6 \times 10^{2}$ & $6.18 \times 10^{-1}$ \\
\hline D & - & $3.55 \times 10^{-1}$ \\
\hline$E$ & $3.8 \times 10^{2}$ & $7.66 \times 10^{-1}$ \\
\hline
\end{tabular}

ることができないと思われる，特に，製䊬用の采状菌は カタラーゼ活性が強いと考光られることから, カタラー セ陽性菌の混在系に叔活る活性の分別測定技術の検討が さらに必要と考光られる。

筆者は食品衛生学的な応用研究の一環として, 酵母之 大腸菌の混在系においては $36 \times g, 10$ 分程度の遠心分画 により酵母のみ沈降させて両菌数を推定する方法を検討 している。また，KROLL ら ${ }^{8)}$ は電荷を有するメンブラ ンフィルターを用いて食品中の細菌をフィルターに集め てカタラーゼ活性を測定する方法により, 食品中の内因 性カタラーゼを除くことができることを報じ；BIosMERU ら 91 は, 夕ラの肉の内因性カタラーゼの失活温度 $41^{\circ} \mathrm{C}$ に対し, Micrococcus sp. が $73^{\circ} \mathrm{C}$, Pseudomonas sp. が $93^{\circ} \mathrm{C}$ と失活温度にかなり大きな差のあることを 利用し, 約 10 分の段階熱処理によりこれらのカタラー セ活性を分画測定して污染菌数の迅速測定が可能なこと を示した。土井ら ${ }^{10)}$ は牛乳の $\mathrm{pH}$ を11 付近の高アル カリに調節することにより，牛乳由来のカタラーゼ活性 が失活して, 細菌由来のカタラーゼ活性が選択的に測定 できることを見出し，原料乳の細菌数の迅速測定に応用 している。このような知見は, 醇造技術方面における本 法の応用を考えていただく際の参考の一助になることを 期待して付記させていただいた。

なお，試料によってはセルフリーのカタラーゼ活性が 高いものもあるのであらかじめそのチェックをしておく ことが重要と考兄られる。

\section{6. ま と め}

1.酸素センサを用いるカタラーゼ活性測定法の利点 および好適な測定装置を紹介した。

2. ワイン, ビール, お上び清酒醸造醳拇の增殖過程 におけるカタラーゼ活性の消長の測定を行い, カタラー ゼ活性係数 $K_{c}\left(\mu \mathrm{mol} \mathrm{H} \mathrm{H}_{2} \mathrm{O}_{2} / \mathrm{sec} /\right.$ single cell $)$ が $10^{-10}$ のオーダーとなることを示した。

3.とのカタラーゼ活性には, 環境の酸素供給度が影 響を及洔すことを示した。

4. カタラーゼ活性により醸造酲母の生菌数の迅速推 定の可能性を考察した。

$$
\text { 〈(株)モリテックス> }
$$




\section{謝辞}

上記研究はお茶の水女子大学家政学部栄養化学研究室 において平成 2 年度に行ったものである。

終始御懇篤な御指導を賜った荒川信彦先生ならびに大 堟患先生，真摰な協力を下さった卒業論文研究生高野尚 美さん，本稿執筆の好機を賜った（社）中央味噌研究所 所長海老根英雄先生の皆様に深謝申し上げます。

また, 本研究に用いた酵母菌株は, 理化学研究所系統 保存施設の高島珀子先生, 東京大学応用微生物研究所 (現・分子細胞生物学研究所) 戸田 清先生の御厚意に よるものであり，ここに哀心より感謝申し上げあす。

\section{文献}

1) 大橋 実, 押谷五月, 大塚 恵, 荒川信彦：食衛 誌, 32, 71 (1991)

2）厚生省環境衛生局食品化学課編：食品中の食品添
加物分析法, p. 24, 講談社 (1982)

3）東京大学農芸化学教室：実験農芸化学下，第 11 版, p.624, 朝倉書店 (1971)

4) E. Hugo : Aebi, Catalase, in Methods of Enzymatic Analysis (H. U. Bergmeyer ed.), 3, 273, Verlay Chemie, Weinheim (1983)

5) 梅本 滋, 大橋 実, 宇津木義雄 : 東海区水研 報，第 118 号, p.59 (1985)

6) N. Koyama, M. Aoyama and M. Nagahisa: Plant \& Cell Physiol., 9, 441 (1968)

7) B. Ephrussi, P. P. Sloninski, Y. Yotuyanagi and J. Tavlitzki : C. R. Lab. Carlsberg, Ser. Physiol., 26, 87 (1956)

8) R. G. Kroll, E. R. Frears and A. Bayliss : $J$. Appl. Bacteriol., 66, 209 (1989)

9) D. Biosmenu, F. Lepine, M. Gagon and H. Dugas : J. Food Sci., 55, 581 (1990)

10）土井豊彦, 神崎幹雄, 中沼 浩, 橴谷美雪, 松本 清: 日食工誌, 39, 135 (1992) 